\title{
Relative resources and moving from the joint home around divorce
}

\author{
Clara H. Mulder • Barbara ten Hengel · Jan Latten • Marjolijn Das
}

Received: 15 December 2010/Accepted: 24 November 2011/Published online: 8 December 2011

(C) The Author(s) 2011. This article is published with open access at Springerlink.com

\begin{abstract}
We investigated the influence of relative resources on who moves from the marital home around divorce: the man, the woman, or both ex-partners. The likelihood of moving was expected to be smaller with greater relative resources. The study used register data from the Social Statistical Database for the Netherlands and multinomial logistic regression models. We found an asymmetrical effect of relative income: all else being equal, the woman was more likely to move out if her share of the couple's income was less than half, but hardly less likely if it was greater than half. The woman was particularly likely to move out if the couple's home was owner-occupied. Regardless of gender, the older one ex-partner was compared with the other, the less likely that ex-partner was to leave. Moves by both ex-partners were not influenced by relative resources. But they occurred less frequently with higher ages (and thus with longer partnership durations) and with the presence of children in the couple's household. They also occurred less frequently when the couple lived in an owner-occupied home.
\end{abstract}

Keywords Divorce $\cdot$ Residential mobility $\cdot$ Resources

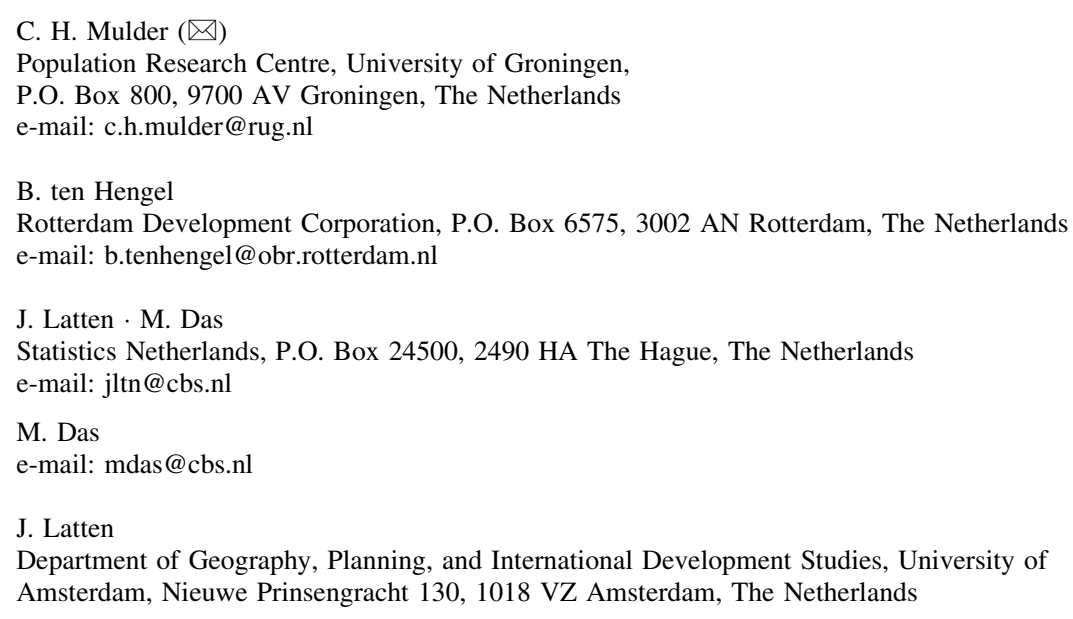




\section{Introduction}

Who gets the house and who moves out? That is one of the major issues ex-partners have to contend with when they get divorced, and one with potentially severe repercussions for the ex-partners' housing careers. The literature addressing this issue is small but growing (Sullivan 1986; Symon 1990; Wasoff and Dobash 1990; Andreß et al. 2003; GramHanssen and Bech-Danielsen 2008; Feijten and Mulder 2010; Mulder and Wagner 2010; (Mulder and Malmberg 2011; Mulder and Wagner forthcoming). The picture emerging from these studies is that the nonmonetary costs of moving are of great importance to the question of who moves out. An ex-partner who gets custody of the children moves out considerably less often (Andreß et al. 2003; Gram-Hanssen and Bech-Danielsen 2008; Mulder and Wagner 2010); an ex-partner who initiated the decision to divorce or who switches to a new partner is much more likely to move out (Mulder and Wagner 2010). The local social network also seems to be important: those with family members living nearby are less inclined to move (Mulder and Malmberg 2011; Mulder and Wagner forthcoming).

There is also some evidence that financial resources play a part in who moves out. As Gram-Hanssen and Bech-Danielsen (2008) have shown for Denmark, employed ex-partners with higher incomes were much less likely to move at the time of divorce than those in less favorable socio-economic positions. Their analysis, however, pertained to individual divorced people rather than ex-couples, so they could not study the impact of relative resources. In contrast, Mulder and Wagner (2010) found some impact of relative resources, but the evidence was not very strong. They found that the woman was less likely to move out if she alone was employed and if she was older than the man (and thus had had more time to accumulate assets and progress in her labor-market career). They also found that the man was less likely to move out if he was five or more years older than the woman. However, they did not have a satisfactory measure of relative income. Using Swedish data, Mulder and Malmberg (2011) also paid some attention to relative resources and found that these mattered, but they did not focus on gender differences.

In this paper, we address the issue of who, in two-gender ex-couples, moves out of the joint home around divorce: the man, the woman, or both. Our research question is: What is the influence of differences between the partners in resources before the divorce on who moves out of the joint home around the divorce? Compared with previous research, our contributions are threefold. First, we use detailed and reliable measurements of relative income and employment status before the divorce. Secondly, we also include an indicator of each partner's resources from the local social network: whether their parents live close. Thirdly, we include the cases in which both ex-partners move out rather than just those in which the man or the woman moves out.

We use register data for the Netherlands for couples who were married and lived at the same address in September 2002 and divorced between September 2003 and September $2004(N=18,217)$. The method of analysis is multinomial logistic regression.

\section{Theoretical background}

\subsection{Starting point}

We depart from the premise that, generally, the recently divorced prefer not to leave the joint home. There are several reasons why this would be the case. First, people are generally not inclined to move unless there is a compelling reason for doing so. In the 
migration literature, this principle is referred to as residential inertia (Huff and Clark 1978; Mulder 1996). This comes about because people tend to accumulate location-specific capital tying them to a place (DaVanzo 1981) and because moving is a stressful event (McCollum 1990; Magdol 2002). The move from the joint home may be particularly stressful because of its connection with the separation, which is already stressful in itself. Because the move out of the joint home is often urgent, a divorced person frequently has to accept accommodation that is of low quality, over-priced, temporary, and possibly shared. In contrast, the ex-partner who stays has one person less to share the house with after the other ex-partner has left. Furthermore, if the joint home was owner-occupied, time and transaction costs are involved for the partner who leaves, who moreover runs the risk of having to re-enter homeownership at a higher price level in times of rapidly rising prices (Gram-Hanssen and Bech-Danielsen 2008). Empirically, an indication that our premise is correct in at least more cases than it is wrong can be derived from the survey Divorce in the Netherlands (SIN, conducted in 1998). This survey contains information about around 1,750 respondents in the Netherlands who divorced between 1947 and 1998. Inspection of this survey revealed that around 30 percent of divorced people who left the home reported they thought the housing outcome of the divorce was to their disadvantage, whereas this was true of only 7 percent of those who stayed.

This is not to say that each and every divorced person prefers to stay in the joint home: some may prefer a 'clean break' or be happy to move in with a new partner. Unfortunately, we do not have information about the preferences of the ex-partners regarding moving or staying. Neither do we have sufficient information about the costs of moving each individual ex-partner is confronted with.

\subsection{The role of relative resources}

Even though moving out may also be costly in monetary terms, the costs of remaining in the joint home after separation are frequently considerable. They need to be afforded from one income only and economies of scale no longer apply. To afford to stay, the individual ex-partner's financial resources need to be sufficient regardless of the other partner's financial situation (Gram-Hanssen and Bech-Danielsen 2008). If neither partner can afford to stay, both may have to move out. A partner who has more resources than the other will have a greater chance of affording to stay in the home (Mulder and Wagner 2010). Furthermore, an ex-partner with more resources than the other may derive greater power from the resource asymmetry and then use that power to argue that the other should move out or even to push the other out.

Obviously, an important financial resource is income. Our first hypothesis, therefore, is: The greater an ex-partner's share in the household income was before the divorce, the less likely it is that that ex-partner leaves the joint home. Savings and debts will also be important, but unfortunately we do not have information about these in our data. Besides financial resources, employment status is also likely to be important. If one partner is employed and the other is not, the employed partner most likely has an advantage in the sense of a higher income potential. At the same time, being employed may also indicate attachment to the local labor market and therefore increase the cost of moving. This is likely to apply even more strongly to the self-employed: self-employment frequently implies local investments that increase the cost of moving.

A difference in resources is also likely if one of the partners is older than the other: the older partner's labor-market career is likely to have progressed further and there has been more time and opportunity to accumulate individual savings (Mulder and Wagner, 2010). 
It is also more likely that the younger partner moved in with the older partner, or that the older partner is the sole owner of the home. Our second hypothesis is: The older an ex-partner is compared with the other, the less likely it is that that ex-partner leaves the joint home.

Resources may also derive from the local social network or other ties to the residential location. If the local network of one partner is stronger than that of the other, the betterconnected partner may be more motivated to stay and use the presence of his or her network to justify wanting to stay in the home. As an indicator of the local social network, we use whether the parents live close by. In many cases the parents will form part of the social network and constitute a tie to the location. But their proximity will often also indicate a long history, for example since birth, at the residential location before the separation. As has been shown by Michielin et al. (2008), people seem to take the residential location of their parents into account in their moving behavior. This also seems to hold for moving around divorce (Mulder and Malmberg 2011; Mulder and Wagner forthcoming). Our third hypothesis is: If an ex-partner's parents live close by, that ex-partner is less likely to move out. An alternative hypothesis about the presence of parents could be that the parents may help find housing or invite their adult child to move in with them, thereby facilitating a move out of the marital home. In fact, divorce is known to be an occasion for some adult children to move in with their parents (e.g. Smits et al. 2010). It should also be noted that, when making a case for the role of the presence of parents, it is just as possible to argue from a cost perspective as from a resource perspective. Indeed, the parents represent location-specific capital (DaVanzo 1981), which increases the cost of moving.

\subsection{Relative resources in relation to total income and housing costs}

Although relative resources may be important in any situation, they are arguably more important when the total income of the couple before divorce is higher. If the total amount is low, both ex-partners will be eligible for social housing and rent allowances. In the context of the Netherlands, social housing is available not only for households with the very lowest incomes, but also for those with middle-low incomes (the social sector makes up around $30 \%$ of the total housing stock). The importance of relative resources will also increase along with the housing costs. If the marital home is expensive, the occupants need more resources to afford it. So the chances are greater that the ex-partner who earned a smaller share of the income will have to move to cheaper accommodation. A similar reasoning holds for owner-occupied homes. The costs of staying in an owner-occupied home are particularly great because the partner who stays usually has to buy out the one who leaves. Our fourth hypothesis is: The impact of relative resources is greater when the total income of the couple was higher before the divorce, the housing value was higher, or the home was owner-occupied.

\subsection{Absolute resources and housing costs}

Apart from the hypothesized differential impact of relative resources, absolute resources may have an impact of their own on who moves out. It is not immediately obvious what to expect with regard to the total household income. One might think that, given a certain income division in the household and given the costs of housing, a higher income would allow any ex-partner easier affordance of the joint home. So with a higher household income there would be fewer cases where both would move. In contrast, with higher costs of housing, staying in the home would be less affordable. A somewhat different argument 
holds for whether the joint home was owner-occupied. There are two reasons to expect the woman to be more likely to move out of an owner-occupied home. First, single ownership of a home inhabited by a couple is more common among men than women, even though it is quite rare. Estimates for the Netherlands in the early 2000s indicate that it was the man who was the sole owner of the house among $4.1 \%$ of couples living in an owner-occupied home, whereas it was the woman among 2.4\% (Feijten and Mulder 2010). Secondly, even when the incomes are equal, men are more likely to have better earning prospects and thus to be in a better position to obtain a mortgage based on a single income. It can also be expected that both ex-partners are more likely to move out of an owner-occupied home. This is because we are observing divorces that took place in a period in which selling prices rose much more rapidly than rents. Buying out an ex-partner may be a serious cost burden in any situation, but particularly after prices have risen. The affordability of owneroccupied homes for one ex-partner could be particularly problematic in the Netherlands, where indebtedness is much higher than in most other countries (Boelhouwer 2002). An alternative hypothesis can be derived from the idea that owner-occupied homes are usually of better quality and situated in better neighborhoods than rented homes. For this reason, homeowners may make an extra effort to keep the house, which would make a move by both ex-partners less likely.

\subsection{Other factors to account for}

There are several other factors that may influence who moves out of the joint home. Apart from age differences, age itself (indicated by the woman's age) is likely to matter. First of all, age can be taken as a proxy, albeit a rough one, for partnership duration, a value we could not derive directly from the data. Women are less likely to move out with increasing partnership duration, even after controlling for whether the couple has children (Mulder and Wagner 2010). Second, with increasing age, the likelihood is also greater that the couple has lived in the same home for a long time and either owns it outright or pays a low rent. This decreases the housing costs and thereby improves the opportunities for either partner to afford the home. We therefore expect the likelihood that both move out to decrease with the woman's age. Because mothers are most likely to get custody of the children, we expect the woman to move out less frequently when the couple was living with dependent children. In that case we also expect the likelihood that both move out to be smaller: It is usually thought to be in the children's best interest if they stay in the family home, so the couple is likely to make an extra effort to facilitate this. People of nonwestern migrant origin may have specific norms about who should stay and who should move. Or their perspective on staying versus moving may be different than that of the native Dutch, given that some migrants might consider moving back to their country of origin. Finally, we account for the degree of urbanization to capture differences among local housing and labor markets.

\section{Data and method}

\subsection{The dataset}

The data were derived from the Social Statistical Database (SSD), housed by Statistics Netherlands (Bakker 2002). The SSD contains administrative data for the entire population registered as living in the Netherlands. The data were obtained from the population 
register, tax registers, social security registers, and various other registers and administrations. From this dataset we selected those people who were married and registered as living at the same address in the Netherlands in September 2002 with or without dependent children; married but not necessarily living at the same address in September 2003; and divorced and not living at the same address in September 2004. This selection was designed to capture cases in which a partner moved out before the divorce became official (these couples were married in 2003 but no longer living at the same address) as well as cases in which the actual separation took place in the same 12 months as the official divorce. We further selected couples of which the woman was 18-54 years old to ensure that the women and most of the men were in the potential labor force and not living on old age pensions.

The selection certainly does not capture all divorces in the Netherlands that took place between 2003 and 2004 among couples of which the woman was 18-54 years old. It does not capture the following categories: same-sex couples; couples who were married but not registered at one address in 2002 (because they had already separated before that time, or because they lived apart for some other reason); couples of which at least one ex-partner remarried in the same 12-month period as the actual divorce; those who married after September 2002 and then divorced between September 2003 and 2004; those ex-couples of which a partner died or emigrated in the remaining months between the divorce and September 2004; those who had divorced but were registered at the same address (for example, because they had remained in the same house even though they were divorced, because they had rejoined, or because they had moved but had not reported their move to the population register; $13.5 \%$ of the otherwise selected); and those of which the partners were registered in 2002 as 'other household members' rather than 'partners' (mainly couples who were living with either partner's parents). Out of around 28,000 divorced excouples in the eligible age category, 18,296 were in the selection. Of these, 18,217 were included in the analyses. The other 79 had missing values on owner-occupancy of the home or degree of urbanization.

\subsection{Method and measures}

The method used was multinomial logistic regression analysis. The categorizations of the dependent and independent variables, their frequencies, and cross-tabulations of the independent variables with the dependent variable are given in Table 1. The dependent variable has three values: the man moved out; the woman moved out; both moved out. It was determined who moved out by checking whether each ex-partner was registered at the same address in 2003 as in 2002 or a different address, or, if the partners still lived together in 2003, at the same address in 2004 as in 2003 or at a different one. We estimated various models: a bivariate model including only the variable for the woman's share in income; a model with the main effects of all independent variables; and three models with these main effects and an interaction between the woman's share in income and one other variable per model. These variables were household income, house value, and whether the home was owner-occupied. For the models with interaction terms, household income and house value were dichotomized.

All independent variables were measured in 2002. The couple's monthly income in euro, and the woman's share in it, was derived from tax registers, social security registers, and the register on student grants. 'Income' therefore consisted of income from wages, profit from self-employment, social benefits, old age pensions, and student grants. Both income variables were categorized. In the variable for the woman's share, a separate 
Table 1 Descriptive statistics of variables and cross-tabulations of who moved out after separation by independent variable

\begin{tabular}{lllll}
\hline $\mathrm{N}$ & \% In data & $\begin{array}{l}\text { Man } \\
\text { moved }\end{array}$ & $\begin{array}{l}\text { Woman } \\
\text { moved }\end{array}$ & $\begin{array}{l}\text { Both } \\
\text { moved }\end{array}$ \\
\hline
\end{tabular}

Who moved out

$\begin{array}{lrr}\text { Man } & 7,029 & 38.6 \\ \text { Woman } & 7,540 & 41.4 \\ \text { Both } & 3,648 & 20.0 \\ \text { Total } & 18,217 & 100.0\end{array}$

Woman's share in income $\left(\chi^{2}=107.536, d f=10, p=0.000, V=0.054\right)$

$\begin{array}{lrrrrr}<0.20 & 6,799 & 37.3 & 38.8 & 42.3 & 18.9 \\ 0.20-0.45 & 7,547 & 41.4 & 35.7 & 43.5 & 20.9 \\ 0.45-0.55 & 1,948 & 10.7 & 42.7 & 35.9 & 21.4 \\ 0.55-0.80 & 1,075 & 5.9 & 46.0 & 36.6 & 17.5 \\ \geq 0.80 & 672 & 3.7 & 46.6 & 32.4 & 21.0 \\ \text { Couple's income } \leq 0 \text { or unknown } & 176 & 1.0 & 34.1 & 42.6 & 23.3\end{array}$

Employee $\left(\chi^{2}=68.471, d f=6, p=0.000, V=0.043\right)$

$\begin{array}{llllll}\text { Neither man nor woman } & 2,063 & 11.3 & 44.6 & 38.5 & 16.8 \\ \text { Man only } & 4,697 & 25.8 & 40.7 & 39.7 & 19.6 \\ \text { Woman only } & 1,847 & 10.1 & 39.1 & 41.7 & 19.2 \\ \text { Both } & 9,610 & 52.8 & 36.2 & 42.8 & 21.1\end{array}$

Self-employed $\left(\chi^{2}=24.901, d f=6, p=0.000, V=0.026\right)$

$\begin{array}{lrrrrr}\text { Neither man nor woman } & 16,073 & 88.2 & 38.9 & 41.0 & 20.1 \\ \text { Man only } & 1,244 & 6.8 & 37.2 & 44.4 & 18.4 \\ \text { Woman only } & 497 & 2.7 & 38.2 & 40.0 & 21.7 \\ \text { Both } & 403 & 2.2 & 30.0 & 51.4 & 18.6\end{array}$

Age difference $\left(\chi^{2}=294.954, d f=10, p=0.000, V=0.090\right)$

$\begin{array}{lrrrrr}\text { Man } \geq 10 \text { years older } & 1,460 & 8.0 & 35.0 & 49.9 & 15.1 \\ \text { Man 5-10 years older } & 3,786 & 20.8 & 35.1 & 46.6 & 18.3 \\ \text { Man 2-5 years older } & 6,092 & 33.4 & 36.0 & 43.4 & 20.6 \\ \text { Age difference } \leq 1 \text { year } & 4,917 & 27.0 & 41.5 & 36.8 & 21.8 \\ \text { Woman 2-5 years older } & 1,250 & 6.9 & 44.5 & 33.6 & 21.9 \\ \text { Woman } \geq 5 \text { years older } & 712 & 3.9 & 56.7 & 24.3 & 19.0\end{array}$

Parent(s) in same municipality $\left(\chi^{2}=132.790, d f=6, p=0.000, V=0.060\right.$ )

$\begin{array}{llllll}\text { Neither man's nor woman's parent(s) } & 7,520 & 41.3 & 38.4 & 41.5 & 20.1 \\ \text { Man's parent(s) } & 3,205 & 17.6 & 33.7 & 47.9 & 18.4 \\ \text { Woman's parent(s) } & 3,821 & 21.0 & 44.6 & 35.3 & 20.1\end{array}$

Couple's income $\left(\chi^{2}=198.908, d f=12, p=0.000, V=0.074\right)$

\begin{tabular}{lrrrrr}
$<0-1,500$ & 1,362 & 7.5 & 46.9 & 35.2 & 17.9 \\
$1,500-2,250$ & 1,655 & 9.1 & 49.7 & 34.1 & 16.2 \\
$2,250-3,000$ & 3,317 & 18.2 & 40.8 & 40.0 & 19.1 \\
$3,000-3,750$ & 3,872 & 21.3 & 37.0 & 41.3 & 21.7 \\
$3,750-4,500$ & 3,010 & 16.5 & 34.0 & 45.1 & 20.9 \\
$4,500-6,000$ & 2,990 & 16.4 & 34.7 & 43.8 & 21.4 \\
$\geq 6,000$ & 2,011 & 11.0 & 35.8 & 44.8 & 19.4 \\
Both man's and woman's parent(s) & 3,671 & 20.2 & 36.9 & 42.0 & 21.2 \\
\hline
\end{tabular}


Table 1 continued

\begin{tabular}{|c|c|c|c|c|c|}
\hline & $\mathrm{N}$ & $\%$ In data & $\begin{array}{l}\text { Man } \\
\text { moved }\end{array}$ & $\begin{array}{l}\text { Woman } \\
\text { moved }\end{array}$ & $\begin{array}{l}\text { Both } \\
\text { moved }\end{array}$ \\
\hline \multicolumn{6}{|c|}{ House value $(€ 1,000 \mathrm{~s})\left(\chi^{2}=176.105 d f=12, p=0.000, V=0.070\right)$} \\
\hline$<100$ & 4,834 & 26.5 & 43.5 & 37.8 & 18.7 \\
\hline $100-125$ & 4,043 & 22.2 & 40.5 & 40.5 & 19.0 \\
\hline $125-150$ & 3,117 & 17.1 & 40.5 & 41.2 & 18.3 \\
\hline $150-200$ & 2,827 & 15.5 & 34.3 & 44.1 & 21.6 \\
\hline $200-300$ & 1,521 & 8.3 & 31.0 & 45.0 & 24.1 \\
\hline$\geq 300$ & 606 & 3.3 & 31.8 & 48.0 & 20.1 \\
\hline Unknown & 1,269 & 7.0 & 30.7 & 44.8 & 24.4 \\
\hline \multicolumn{6}{|c|}{ Child(ren) under $17\left(\chi^{2}=151.766, d f=2, p=0.000, V=0.091\right)$} \\
\hline No children under 17 & 3,401 & 18.7 & 29.3 & 47.8 & 22.8 \\
\hline One or more children under 17 & 14,816 & 81.3 & 40.7 & 39.9 & 19.4 \\
\hline \multicolumn{6}{|c|}{ Migrant status $\left(\chi^{2}=314.182, d f=6, p=0.000, V=0.093\right)$} \\
\hline Native Dutch & 12,662 & 69.5 & 35.8 & 43.6 & 20.6 \\
\hline Non western & 1,484 & 8.1 & 58.6 & 24.3 & 17.1 \\
\hline Western & 392 & 2.2 & 44.9 & 39.5 & 15.6 \\
\hline Mixed & 3,679 & 20.2 & 39.3 & 41.0 & 19.7 \\
\hline \multicolumn{6}{|c|}{ Owner-occupied home $\left(\chi^{2}=1,444.244, d f=2, p=0.000, V=0.282\right)$} \\
\hline No & 6,849 & 37.6 & 56.2 & 30.8 & 13.1 \\
\hline Yes & 11,368 & 62.4 & 28.0 & 47.8 & 24.2 \\
\hline \multicolumn{6}{|c|}{ Degree of urbanization $\left(\chi^{2}=285.532, d f=8, p=0.000, V=0.089\right)$} \\
\hline Not urbanized, $<500$ addresses $/ \mathrm{km}^{2}$ & 3,014 & 16.5 & 29.8 & 51.2 & 19.0 \\
\hline Hardly urbanized, 500-1,000 & 3,833 & 21.0 & 34.9 & 42.8 & 22.2 \\
\hline Moderately urbanized, $1,000-1,500$ & 4,168 & 22.9 & 38.8 & 39.9 & 21.3 \\
\hline Urbanized, 1,500-2,500 & 4,394 & 24.1 & 41.6 & 38.5 & 20.0 \\
\hline \multirow[t]{2}{*}{ Strongly urbanized, $\geq 2,500$} & 2,808 & 15.4 & 48.0 & 35.7 & 16.3 \\
\hline & Mean & Std dev. & & & \\
\hline Age woman & 37.39 & 7.406 & & & \\
\hline
\end{tabular}

category was used for negative incomes. Registered negative incomes are rare; they are mainly found among self-employed people and represent losses. Employment and selfemployment were measured using information from tax registers and were categorized as follows: neither ex-partner (self)employed, man only (self)employed, woman only (self)employed, both (self)employed. Age and age difference were measured in years; the difference was categorized. Whether the parents lived close by was measured with four categories: no parent of either partner living in the same municipality as the couple; at least one parent of the man; at least one parent of the woman; at least one parent of both partners.

A dummy variable indicates whether the couple had children younger than 17 living with them. Migrant status was measured using the standard definition of Statistics Netherlands. Those with at least one parent born abroad are considered to be of migrant origin (either the first or the second generation). A further distinction is made between western migrants (those originating from Europe (excluding Turkey), North America, Oceania, Japan, or Indonesia) and non-western migrants (those originating from all other countries). 
House values are registered for taxation purposes and reflect the market value; they are mainly based on recent transactions of similar dwellings in the same neighborhood. A separate category was used for unknown house values $(7 \%)$; these are most common in new construction.

A home is registered as owner-occupied if a person who owns it (alone or with one or more co-owners) lives in the home. Unfortunately, the data do not reveal who is the owner: the man, the woman, the couple, or someone else who lives in the home. The degree of urbanization was measured using the number of addresses per square kilometer in the neighborhood.

\section{Results}

Looking at the descriptive statistics in Table 1, it is interesting to note that the woman moved out somewhat more frequently than the man (41\% vs. 39\%) and that both expartners moved out in a considerable percentage of cases (20\%). This result is markedly different from the finding by Feijten and Mulder (2010), also for the Netherlands and the early 2000s but with data from the Netherlands Kinship Panel Study (NKPS). They found that the man moved out in 43 percent of the cases, the woman in 50 percent, and both in 7 percent. Part of this difference in findings could be caused by the incomplete coverage of separations in our data. Another likely cause is the fact that the information in NKPS referred to the moment of separation and probably includes unregistered moves to temporary accommodation that cannot be traced in the SSD data but, unlike SSD, does not cover moves a few months after the divorce of those ex-partners who initially stayed. This interpretation is consistent with previous research on a small sample of British owneroccupiers. In that sample, immediately upon separation, in 58 percent of cases the husband left, in 39 percent the wife left, and in 3 percent both left (Symon 1990). After the official settlement of the divorce, however, in many more cases it was the female ex-partner who moved, leading in the end to more women than men moving out of the marital home. Also note that in a previous study based on register data, Gram-Hanssen and Bech-Danielsen (2008) concluded for Denmark that, around the separation of cohabiting and married couples, women left the joint home slightly more frequently than men and in no less than 30 percent of the cases both ex-partners left. For Sweden, Mulder and Malmberg (2011) reported 24 percent of such cases, although cohabiting couples without children were not represented in their dataset.

Relative income mattered with respect to who moved out, but not symmetrically. Where a small share of the income was contributed by the woman, the likelihood that she, and not the man, would move out was estimated to be greater than among couples contributing equally (see Tables 2 and 3). There were, however, only weak signs that the woman was less inclined to move out when she contributed more. If she contributed $55-80 \%$, the woman was estimated to be just about as likely to move out as when she contributed $45-55 \%$; if she contributed more than $80 \%$, she was estimated to be less likely to move. However, the difference from those contributing an equal share was smaller than when she contributed less than half. It was only marginally significant in the bivariate analysis (Table 2) and insignificant in the multivariate analysis (Table 3). It should be noted that couples where the woman contributed more formed a select category of couples. Many had low incomes (47\% compared with $6.7 \%$ of the total research population). It is also noteworthy that, in the model with relative income only (Table 2), the woman was estimated to be more likely to move out compared with the man when the household had no income or a 
Table 2 Multinomial logistic regression of who moved out, parameters of a model with woman's share in couple's income only

\begin{tabular}{|c|c|c|c|c|c|c|}
\hline & \multicolumn{3}{|c|}{ Woman moved out } & \multicolumn{3}{|c|}{ Both moved out } \\
\hline & Coeff. & $p>|z|$ & $\operatorname{Exp}(B)$ & Coeff. & $p>|z|$ & $\operatorname{Exp}(B)$ \\
\hline Intercept & $-\mathbf{0 . 1 7 3}$ & 0.001 & & -0.693 & 0.000 & \\
\hline \multicolumn{7}{|c|}{ Woman's share in income (ref. 0.45-0.55) } \\
\hline$<0.20$ & 0.259 & 0.000 & 1.295 & -0.023 & 0.734 & 0.977 \\
\hline $0.20-0.45$ & 0.370 & 0.000 & 1.448 & 0.156 & 0.022 & 1.169 \\
\hline $0.55-0.80$ & -0.056 & 0.509 & 0.946 & -0.273 & 0.009 & 0.761 \\
\hline$\geq 0.80$ & -0.189 & 0.064 & 0.828 & -0.104 & 0.376 & 0.901 \\
\hline Couple's income $\leq 0$ or unkown & 0.396 & 0.028 & 1.486 & 0.312 & 0.139 & 1.367 \\
\hline
\end{tabular}

Reference: man moved out

Parameters in bold differ from zero at the $5 \%$ level

negative income than when both partners contributed equally. As mentioned in the Data section, part of the negative and zero incomes are found among the self-employed; businesses are more frequently owned by the male than the female partner. In the full model, a similar effect was found even after controlling for self-employment.

The interaction between the woman's share in the household income and three indicators of socio-economic status (household income, house value and home-ownership) shows that the effect of relative income is most pronounced for higher household incomes and homeowners, as expected (Table 4). To a lesser extent, this is also true for higher house values. Interestingly, there seems to be more symmetry in the relative income effect for those with higher incomes (see the significant negative parameters for a high share of the woman's income in the interaction with the couple's income).

We also see an impact of employment and self-employment, but this impact is not in line with expectations. If only the man was employed or self-employed, the woman was not significantly more likely to move out, rather than the man, than if none of the expartners were employed or self-employed. All else being equal, employment of only the woman had a positive rather than a negative effect on her likelihood of moving out. Another notable finding is the marked positive effect of self-employment of both partners, rather than neither of them, on the woman's likelihood of moving out. When a married couple has a joint business, usually only one partner is registered as self-employed whereas the other is registered as working in the family business. So, when both the man and the woman are self-employed, this usually means that the man and the woman each own a separate business. Probably in most cases the man's business is larger than that of the woman, which puts the man in a better position to keep the house.

A considerable impact of age differences between the partners was found, and in the expected direction. The more years the man was older than the woman, the more likely the woman was to move out. Conversely, the woman's probability of moving out was smaller if she was five or more years older than the man than if the partners were of about equal age (but not significantly less likely if she was two to five years older). So, the effect of age differences seems to be more symmetrical than that of relative income. The differences between the categories in the age difference variable are also estimated to be greater than those in the relative income variable, suggesting a greater impact of age differences than of relative income. Compared with relative income, which could change from year to year, an age difference may indicate a longer-term difference in progression in the labor-market and 
Table 3 Multinomial logistic regression of who moved out

\begin{tabular}{|c|c|c|c|c|c|c|}
\hline & \multicolumn{3}{|c|}{ Woman moved out } & \multicolumn{3}{|c|}{ Both moved out } \\
\hline & Coeff. & $p>|z|$ & $\operatorname{Exp}(B)$ & Coeff. & $p>|z|$ & $\operatorname{Exp}(\mathrm{B})$ \\
\hline Intercept & 0.165 & 0.302 & & 1.236 & 0.000 & \\
\hline \multicolumn{7}{|c|}{ Woman's share in income (ref. $0.45-0.55$ ) } \\
\hline$<0.20$ & 0.336 & 0.000 & 1.399 & 0.066 & 0.423 & 1.068 \\
\hline $0.20-0.45$ & 0.319 & 0.000 & 1.376 & 0.123 & 0.100 & 1.130 \\
\hline $0.55-0.80$ & -0.053 & 0.563 & 0.948 & -0.190 & 0.090 & 0.827 \\
\hline$\geq 0.80$ & -0.154 & 0.200 & 0.857 & -0.102 & 0.471 & 0.903 \\
\hline Couple's income $\leq 0$ or unknown & 0.440 & 0.034 & 1.552 & 0.287 & 0.237 & 1.332 \\
\hline \multicolumn{7}{|l|}{ Employee (ref. neither man nor woman) } \\
\hline Man only & 0.108 & 0.217 & 1.114 & -0.040 & 0.718 & 0.961 \\
\hline Woman only & 0.292 & 0.002 & 1.339 & 0.185 & 0.109 & 1.204 \\
\hline Both & 0.170 & 0.053 & 1.185 & -0.066 & 0.548 & 0.936 \\
\hline \multicolumn{7}{|c|}{ Self-employed (ref. neither man nor woman) } \\
\hline Man only & 0.100 & 0.264 & 1.105 & -0.184 & 0.102 & 0.832 \\
\hline Woman only & -0.115 & 0.311 & 0.891 & -0.032 & 0.811 & 0.968 \\
\hline Both & 0.565 & 0.000 & 1.759 & 0.048 & 0.790 & 1.049 \\
\hline \multicolumn{7}{|c|}{ Age difference (ref. age difference $\leq 1$ year) } \\
\hline Man $\geq 10$ years older & 0.862 & 0.000 & 2.367 & 0.032 & 0.734 & 1.033 \\
\hline Man 5-10 years older & 0.569 & 0.000 & 1.766 & 0.028 & 0.663 & 1.028 \\
\hline Man 2-5 years older & 0.318 & 0.000 & 1.375 & 0.041 & 0.447 & 1.042 \\
\hline Woman 2-5 years older & -0.065 & 0.392 & 0.937 & 0.118 & 0.177 & 1.125 \\
\hline Woman $\geq 5$ years older & -0.499 & 0.000 & 0.607 & 0.044 & 0.700 & 1.045 \\
\hline \multicolumn{7}{|c|}{ Parent(s) in same municipality [ref. neither man's nor woman's parent(s)] } \\
\hline Man's parent(s) & 0.320 & 0.000 & 1.377 & -0.038 & 0.552 & 0.962 \\
\hline Woman's parent(s) & $-\mathbf{0 . 3 1 0}$ & 0.000 & 0.734 & -0.247 & 0.000 & 0.781 \\
\hline Both man's and woman's parent(s) & 0.004 & 0.945 & 1.004 & -0.162 & 0.008 & 0.850 \\
\hline \multicolumn{7}{|c|}{ Couple's income (ref. $€<1,500$ per month) } \\
\hline $1,500-2,250$ & $-\mathbf{0 . 3 2 7}$ & 0.001 & 0.721 & -0.279 & 0.022 & 0.757 \\
\hline $2,250-3,000$ & -0.151 & 0.111 & 0.860 & -0.079 & 0.501 & 0.924 \\
\hline $3,000-3,750$ & -0.165 & 0.090 & 0.848 & -0.022 & 0.857 & 0.979 \\
\hline $3,750-4,500$ & -0.089 & 0.380 & 0.915 & -0.107 & 0.398 & 0.889 \\
\hline $4,500-6,000$ & -0.261 & 0.012 & 0.770 & -0.223 & 0.083 & 0.800 \\
\hline$\geq 6,000$ & -0.381 & 0.001 & 0.683 & -0.480 & 0.000 & 0.619 \\
\hline \multicolumn{7}{|l|}{ House value $(€ 1,000$ s; ref. $<100)$} \\
\hline $100-125$ & -0.125 & 0.017 & 0.882 & $-\mathbf{0 . 1 3 8}$ & 0.033 & 0.871 \\
\hline $125-150$ & -0.307 & 0.000 & 0.735 & -0.325 & 0.000 & 0.723 \\
\hline $150-200$ & -0.230 & 0.000 & 0.794 & -0.058 & 0.451 & 0.944 \\
\hline $200-300$ & -0.150 & 0.063 & 0.860 & 0.209 & 0.029 & 1.233 \\
\hline$\geq 300$ & -0.105 & 0.354 & 0.900 & 0.142 & 0.306 & 1.153 \\
\hline Unknown & 0.057 & 0.479 & 1.058 & 0.228 & 0.015 & 1.256 \\
\hline Owner-occupied home & 1.163 & 0.000 & 3.201 & 1.420 & 0.000 & 4.138 \\
\hline Child(ren) under 17 & -0.687 & 0.000 & 0.503 & -0.578 & 0.000 & 0.561 \\
\hline
\end{tabular}


Table 3 continued

\begin{tabular}{|c|c|c|c|c|c|c|}
\hline & \multicolumn{3}{|c|}{ Woman moved out } & \multicolumn{3}{|c|}{ Both moved out } \\
\hline & Coeff. & $p>|z|$ & $\operatorname{Exp}(B)$ & Coeff. & $p>|z|$ & $\operatorname{Exp}(B)$ \\
\hline \multicolumn{7}{|l|}{ Migrant status (ref. native Dutch) } \\
\hline Non western & -0.605 & 0.000 & 0.546 & -0.334 & 0.000 & 0.716 \\
\hline Western & -0.153 & 0.200 & 0.858 & -0.269 & 0.090 & 0.764 \\
\hline Mixed & -0.015 & 0.735 & 0.985 & 0.012 & 0.831 & 1.012 \\
\hline \multicolumn{7}{|c|}{ Degree of urbanization (ref. $<500$ addresses $/ \mathrm{km}^{2}$ ) } \\
\hline Hardly urbanized, $500-1,000$ & -0.248 & 0.000 & 0.780 & 0.083 & 0.251 & 1.086 \\
\hline Moderately urbanized, $1,000-1,500$ & -0.351 & 0.000 & 0.704 & 0.019 & 0.788 & 1.019 \\
\hline Urbanized, $1,500-2,500$ & $-\mathbf{0 . 3 3 1}$ & 0.000 & 0.718 & 0.033 & 0.644 & 1.034 \\
\hline Strongly urbanized, $\geq 2,500$ & -0.410 & 0.000 & 0.663 & -0.198 & 0.019 & 0.820 \\
\hline Age woman & $-\mathbf{0 . 0 0 7}$ & 0.013 & 0.993 & -0.054 & 0.000 & 0.947 \\
\hline Goodness-of-fit: deviance in $\chi^{2}$ & \multicolumn{6}{|c|}{$35,018.451$} \\
\hline$d f, p$ & \multicolumn{6}{|c|}{$35,682,0.994$} \\
\hline Nagelkerke $R^{2}$ & \multicolumn{6}{|l|}{0.164} \\
\hline
\end{tabular}

Reference: man moved out $(\mathrm{N}=18,217)$

Parameters in bold differ from zero at the $5 \%$ level

Table 4 Multinomial logistic regressions of who moved out (reference = man moved out): Interaction effects with woman's share in income

\begin{tabular}{|c|c|c|c|c|c|c|}
\hline & \multicolumn{3}{|c|}{ Woman moved out } & \multicolumn{3}{|c|}{ Both moved out } \\
\hline & Coeff. & $p>|z|$ & $\operatorname{Exp}(B)$ & Coeff. & $p>|z|$ & $\operatorname{Exp}(B)$ \\
\hline \multicolumn{7}{|c|}{ Couple's income $>€ 3,750$ per month and } \\
\hline$<0.20$ & 0.414 & 0.001 & 1.513 & 0.305 & 0.046 & 1.357 \\
\hline $0.20-0.45$ & 0.405 & 0.001 & 1.499 & 0.047 & 0.750 & 1.048 \\
\hline $0.55-0.80$ & -0.555 & 0.002 & 0.574 & -0.659 & 0.003 & 0.517 \\
\hline$\geq 0.80$ & -0.573 & 0.113 & 0.564 & -0.438 & 0.281 & 0.645 \\
\hline \multicolumn{7}{|l|}{ House value $>€ 125,000$ and } \\
\hline$<0.20$ & 0.258 & 0.040 & 1.294 & 0.233 & 0.117 & 1.262 \\
\hline $0.20-0.45$ & 0.063 & 0.615 & 1.065 & 0.042 & 0.773 & 1.043 \\
\hline $0.55-0.80$ & -0.365 & 0.045 & 0.694 & -0.459 & 0.038 & 0.632 \\
\hline$\geq 0.80$ & 0.175 & 0.430 & 1.191 & -0.128 & 0.613 & 0.880 \\
\hline Couple's income $\leq 0$ or unknown & 0.345 & 0.384 & 1.411 & -0.114 & 0.800 & 0.892 \\
\hline \multicolumn{7}{|l|}{ Owner-occupied home and } \\
\hline$<0.20$ & 0.929 & 0.000 & 2.533 & 0.568 & 0.000 & 1.764 \\
\hline $0.20-0.45$ & 0.670 & 0.000 & 1.954 & 0.235 & 0.124 & 1.265 \\
\hline $0.55-0.80$ & -0.542 & 0.002 & 0.581 & -0.363 & 0.105 & 0.696 \\
\hline$\geq 0.80$ & -0.264 & 0.219 & 0.768 & $-\mathbf{0 . 6 0 0}$ & 0.016 & 0.549 \\
\hline Couple's income $\leq 0$ or unknown & 0.621 & 0.116 & 1.860 & -0.382 & 0.390 & 0.682 \\
\hline
\end{tabular}

Parameters from separate models also including all variables in the model shown in Table 3. Parameters in bold differ from zero at the $5 \%$ level 
particularly housing careers. The likelihood that a partner already lived in the home before the start of the partnership, for example, is arguably greater when that partner is older than the other. An age difference may therefore indicate a more strongly established power difference.

A very marked association was found between the woman's versus the man's likelihood of moving out and the presence of the man's and the woman's parents. The woman moved out considerably more frequently when at least one parent of only the man lived in the same municipality but considerably less frequently when at least one of her own parents did. As one would expect, no significant difference was found between a situation whereby both ex-partners had a parent living close by and a situation whereby none did in the woman's rather than the man's likelihood of moving out. As mentioned in the Theory section, we see the proximity of parents as an indicator of the presence of a local social network and/or other ties to the location. The alternative hypothesis - that parents living close by tend to facilitate moving out by offering a place to stay or helping find accommodation - was not supported. It is known that divorce is associated with an increased probability of moves back to the parental home (Smits et al. 2010), but apparently such moves are not common enough to outweigh the social network aspects of proximity of parents.

Most relative resource indicators did not seem to have a strong effect on the likelihood of both ex-partners moving out compared with that of only the man moving out. Apparently, relative resources are mainly influential in those cases where at least one ex-partner can afford to stay, as one would expect. The nearby presence of parents formed an exception. Proximity of the woman's parents, and both partners' parents, was associated with a smaller likelihood of moves by both partners. Possibly, those whose parents live close by make an extra effort to keep the house in the family.

With higher household incomes, it was less likely that the woman moved out, all else being equal (note that this is only found in the multivariate model, after controlling for house value). The main difference was between couples with the lowest household income category and some of the other categories, including the two highest. Women were particularly unlikely to move out of homes with middle house values. Moves by both expartners, compared with moves of the man, seem to be the least frequent among couples with the highest incomes and among those with moderate house values (all else being equal). But they are more frequent among couples with rather high house values ( $€$ 200,000-300,000) and those with unknown house values. The latter are mostly associated with newly constructed homes and therefore with shorter durations of residence as well. A considerable effect was found for home-ownership. If the couple lived in an owneroccupied home, it was much more likely that either the woman or both ex-partners moved out rather than the man. This result was as expected, but it should be noted that the difference between those in owner-occupied homes and rented home was remarkably large. Compared with the man, the woman was estimated to have more than three times higher odds of moving out if the home was owner-occupied than if it was rented, and it was more than four times as likely that both moved out.

As expected, the female partner was less inclined to move out with increasing age and if the couple had children aged below 17 living in the household. The woman was less likely to move out among non-western immigrant couples; for such couples, it was also less likely that both ex-partners moved out. Finally, the woman was less likely to move out in more urbanized areas and it was less likely that both ex-partners moved out in strongly urbanized areas. 


\section{Conclusion}

In this article, we have investigated the impact of relative resources on moves around divorce. We found rather strong evidence in favor of our general hypothesis that individuals who have more resources than their ex-partner are less likely to move. This was found for relative income, age differences (indicating further progression in the labormarket career and more time and opportunity to have accumulated individual savings), and the presence of at least one parent in the same municipality.

The impact of relative resources appeared to be gendered. The positive association between a higher income of the man and the woman's likelihood of moving was stronger than the negative association between a higher income of the woman and her likelihood of moving, although there was more gender symmetry among those with high household incomes. Furthermore, in cases where both partners were self-employed the woman was particularly likely to move out.

We based our relative resources hypothesis on the premise that divorced people tend to prefer staying in the joint home. The support for this hypothesis might be seen as indirect support for this premise: apparently, divorced people tend to use their resources to stay rather than to move to a new place. Such a preference for staying is consistent with the general idea that people prefer not to move unless there is a compelling reason for doing so (Mulder 1996).

Among the other findings, the strong effect of home-ownership stands out. If the couple lived in an owner-occupied home, the woman was much more likely to move, and moves of both partners were also much more likely. Apparently, at least in the Netherlands in the early 2000s, not only were men in an advantaged position in keeping an owner-occupied home, but the likelihood that one partner could afford such a home alone was much smaller than for rented homes.

Our analysis is restricted to the event of moving. We assumed that moving out of the joint home would lead to a decrease in housing quality in most cases; in fact it is known from previous research that divorce is often associated with decreasing housing quality. In future research, it would be interesting to investigate how the housing careers of both ex-partners develop after the separation, and how differences in their careers are related to who moved out.

We have used register data from the Social Statistical Database housed by Statistics Netherlands. Compared with survey data, this dataset has three major advantages. First, the number of observations is much larger than in any survey, leading to greater statistical power. Secondly, the data do not suffer from selective non-response among divorced people. Selective non-response among divorced people is often serious (Mitchell 2010), and there are indications that it is particularly serious among those divorced persons who have moved (Mulder and Wagner 2010). Thirdly, the data contain reliable information about house values and each ex-partner's income that is not affected by memory error, item non-response, or ignorance.

However, administrative registers may suffer from types of errors similar to those in surveys, such as measurement errors and population coverage errors. Moreover, administrative registers have specific problems, such as administrative delay (an event is registered with a certain time lag; Bakker 2010). For example, even though people living in the Netherlands have a legal obligation to report changes in address to the population register within a few days' time, some movers may not comply or do so much later than required. 
Another difference between SSD and most survey data-which is neither necessarily an advantage nor a disadvantage-is the measurement of who moves around divorce. Whereas survey questions usually address directly who moved when the couple separated, SSD refers to registered moves over a longer period of time. The advantage of this measurement is that it disregards temporary situations: either moves to temporary accommodation or short-lived stays of one ex-partner in the marital home.

The information in the registers is collected for administrative rather than statistical purposes. As a matter of course, it is therefore not tailor-made to answer the research questions of social scientists. This implies that not all the variables that we would have preferred to include in the analyses were actually available. Although it is known whether the home in which the couple lived was occupied by the owner, it is unknown who exactly owned the home: the man, the woman, the couple, or someone else living in the household. Unfortunately, no data were available for separations of cohabiting unmarried couples. Neither were data available about several major determinants of who moved out: for example, who took the initiative of the decision to separate; whether a new relationship of either partner was a reason for the divorce; and who got custody of the children after the divorce.

Another major limitation of the data is the limited coverage of divorces. As explained in the data section, there were quite a few categories of divorced people that could not be included in the analysis. This resulted in a loss of about one-third of the total population of those who got divorced in the period under study. Even though this loss is considerably less than the usual non-response in a survey, it is still problematic that we have so little information on the size of the various categories of lost divorces. Furthermore, we hardly have a clue about the extent to which the divorced people who are not in the data form a select category behaving in a different way than those who are in it. We simply do not know, for example, why some divorced people would still be registered at the same address. Some will have rejoined, some might never have actually separated even though they filed for an official divorce, and some might have ended their relationship but are still sharing the house. For these categories, it is irrelevant to ask who moved. Others, however, might have financial or other practical reasons not to register their new address, and still others might have forgotten to register.

On balance, we believe the advantages of the data outweigh the disadvantages and that the analysis of register data is a promising avenue along which insights into the causes and consequences of divorce can be improved.

Acknowledgments Clara Mulder's research was made possible by the Netherlands Organisation for Scientific Research (NWO), VICI grant no. 453-04-001. She did most of the work for this paper when she was a member of the Urban Geographies group of the Department of Geography, Planning and International Development Studies of the University of Amsterdam. Barbara ten Hengel's contribution was made when she was a master student at the Department of Geography, Planning and International Development Studies of the University of Amsterdam.

Open Access This article is distributed under the terms of the Creative Commons Attribution Noncommercial License which permits any noncommercial use, distribution, and reproduction in any medium, provided the original author(s) and source are credited.

\section{References}

Andreß, H.-J., Borgloh, B., Gullner, M., \& Wilking, K. (2003). Wenn aus Liebe rote Zahlen werden. Über die wirtschaftlichen Folgen von Trennung und Scheidung. Wiesbaden: Westdeutscher Verlag. 
Bakker, B. F. M. (2002). Statistics Netherlands' approach to social statistics: The social statistical dataset. Statistics Newsletter, 11, 4-6.

Bakker, B. F. M. (2010). Micro-integration. State of the art. Paper presented for the joint UNECE-Eurostat expert group meeting on registered based censuses, The Hague 10-11.

Boelhouwer, P. J. (2002). Capital accumulation via home-ownership: The case of the Netherlands. European Journal of Housing Policy, 2(2), 167-181.

DaVanzo, J. (1981). Repeat migration, information costs, and location-specific capital. Population and Environment, 4, 45-73.

Feijten, P., \& Mulder, C. H. (2010). Gender, divorce and housing-a life course perspective. In D. Reuschke (Ed.), Wohnen und Gender. Theoretische, politische, soziale und räumliche Aspekte (pp. 175-193). Wiesbaden: VS Verlag für Sozialwissenschaften.

Gram-Hanssen, K., \& Bech-Danielsen, C. (2008). Home dissolution: What happens after separating? Housing Studies, 23(3), 507-522.

Huff, J. O., \& Clark, W. A. V. (1978). Cumulative stress and cumulative inertia: A behavioral model of the decision to move. Environment and Planning A, 10, 1101-1119.

Magdol, L. (2002). Is moving gendered? The effects of residential mobility on the psychological well-being of men and women. Sex Roles, 47(11/12), 553-560.

McCollum, A. T. (1990). The trauma of moving: Psychological issues for women. Newbury Park: Sage Publications.

Michielin, F., Mulder, C. H., \& Zorlu, A. (2008). Distance to parents and geographical mobility. Population, Space and Place, 14, 327-345.

Mitchell, C. (2010). Are divorce studies trustworthy? The effects of survey nonresponse and response errors. Journal of Marriage and Family, 72(4), 893-905.

Mulder, C. H. (1996). Housing choice: Assumptions and approaches. Netherlands Journal of Housing and the Built Environment, 11(3), 209-232.

Mulder, C. H., \& Malmberg, G. (2011). Moving related to separation: Who moves and to what distance. Environment and Planning A, 43(11), 2589-2607.

Mulder, C. H., \& Wagner, M. (2010). Union dissolution and mobility: Who moves from the family home after separation? Journal of Marriage and Family, 72(5), 1263-1273.

Mulder, C. H., \& Wagner, M. (Forthcoming). Moving after separation: The role of location-specific capital. Housing Studies.

Smits, A. W. M., Van Gaalen, R., \& Mulder, C. H. (2010). Parent-child coresidence: Who moves in with whom and for whose needs? Journal of Marriage and Family, 72(4), 1022-1033.

Sullivan, O. (1986). Housing movements of the divorced and separated. Housing Studies, 1(1), 35-48.

Symon, P. (1990). Marital breakdown, gender and home ownership: The owner-occupied home in separation and divorce. In P. Symon (Ed.), Housing and divorce (pp. 110-138). Glasgow: University of Glasgow.

Wasoff, F., \& Dobash, R. E. (1990). Moving the family: Changing housing circumstances after divorce. In P. Symon (Ed.), Housing and divorce (pp. 139-166). Glasgow: University of Glasgow. 